\title{
Synthesis and characterization of nickel and palladium complexes containing hetero-multidentate PNO ligands
}

\author{
Srinivas R. Korupoju, Rung-Yi Lai, Yi-Hong Liu, Shie-Ming Peng, Shiuh-Tzung Liu * \\ Department of Chemistry, National Taiwan University, 1, Section 4, Roosevelt Road, Taipei 106, Taiwan, ROC
}

Received 18 September 2004; accepted 14 March 2005

Available online 26 April 2005

\begin{abstract}
Formation of mono- and dinuclear complexes containing ligands stemmed from the condensation of 2,6-diformyl-4-methylphenol derivatives with 2-(diphenylphosphino)aniline $(\mathbf{P} \sim \mathbf{N})$ was investigated. Condensation of $\mathbf{P} \sim \mathbf{N}$ with 2,6 -diformyl-4-methylanisole yielded the desired bis(imine-phosphine) $\mathbf{L}_{3}$, but provided the cyclized benzoazaphospholium compound with 2,6-diformyl-4methylphenol. Complexation of $\mathbf{L}_{\mathbf{3}}$ with $(\mathrm{COD}) \mathrm{PdCl}_{2}$ gave the dinuclear complex $\mathbf{4}$. On the other hand, $\mathbf{L}_{\mathbf{3}}$ underwent the intramolecular cyclization in the presence of $(\mathrm{DME}) \mathrm{NiCl}_{2}$ via the formation of benzoazaphospholium rings. Template condensation of 2,6-diformyl-4-methylphenol with $\mathbf{P} \sim \mathbf{N}$ in the presence of metal ions yielded the mononuclear nickel(II) and palladium(II) complexes, respectively.
\end{abstract}

(c) 2005 Elsevier B.V. All rights reserved.

Keywords: Iminophosphine; Heterotridentate; Nickel; Palladium; Multidentate

\section{Introduction}

There is a considerable interest in the design and synthesis of ligands consisting of both soft and hard donors to accommodate metal ions for fine-tuning their properties [1]. Accordingly, unsymmetrical bidentate ligands with a nitrogen and a phosphorus donor atoms [referred to as PN ligands] have received much attention recently, due to the distinct trans effect of these donors [2]. Furthermore, heterotridentate PNO ligands resulted from the combination of $\mathbf{P N}$ with an extra oxygen donor displaying unique features in manipulating the catalytic activity on polymerization [3,4]. Several other known PNO ligands involving an $o$-phenylene $\mathbf{P N}$ frame are appeared in Chart 1. Ligand $\mathbf{L}_{\mathbf{A}}$ was studied for the coordination toward $\mathrm{Fe}(\mathrm{III}), \mathrm{Co}(\mathrm{III})$ and $\mathrm{Re}(\mathrm{V})$ ions [5],

\footnotetext{
${ }^{*}$ Corresponding author. Tel.: +88622366 0352; fax: +88622363 6359.

E-mail address: stliu@ntu.edu.tw (S.-T. Liu).
}

whereas ligand $\mathbf{L}_{\mathbf{B}}$ demonstrated the versatility in the formation of $\mathrm{Ni}(\mathrm{II})$ [6a], $\mathrm{Pd}(\mathrm{II})$ [4,6], $\mathrm{Pt}(\mathrm{II})$ [6], and $\mathrm{Ru}(\mathrm{II})$ [7] complexes as a tridentate. The binuclear $\mathrm{Rh}(\mathrm{I})$ complexes of ligand $\mathbf{L}_{\mathbf{C}}$ were studied for hydrosilylation of ketones [8]. In our laboratory, the coordination behavior of ligand $\mathbf{L}_{\mathbf{D}}$ toward palladium(II) was investigated $[9,10]$. Continuing this trend, we pursue to synthesize new multi-chelating ligands $\mathbf{L}_{n}$ (Scheme 1) from 2,6-diformyl-4-methylphenol and study the coordination ability of these related mutlidentates toward $\mathrm{Pd}(\mathrm{II})$ and $\mathrm{Ni}(\mathrm{II})$ ions.

\section{Results and discussion}

\subsection{Preparation of ligands}

In an attempt to synthesize the ligand $\mathbf{L}_{\mathbf{2}}$ by the condensation of 2,6-diformyl-4-methylphenol with 2-(diphenylphosphino)aniline $(\mathbf{P} \sim \mathbf{N})(1: 2)$ in the presence of a 


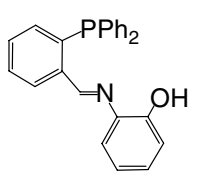

$\mathrm{L}_{\mathrm{A}}$<smiles>[Y]c1ccc(/C=N/c2ccccc2P)c(O)c1</smiles>

$\mathbf{L}_{\mathbf{B}}$

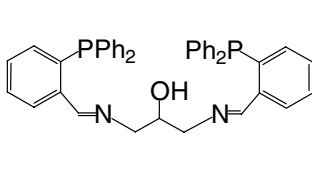

$\mathbf{L}_{\mathrm{c}}$

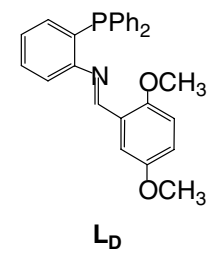

$\mathrm{L}_{\mathrm{D}}$

Chart 1. Various PNO ligands.

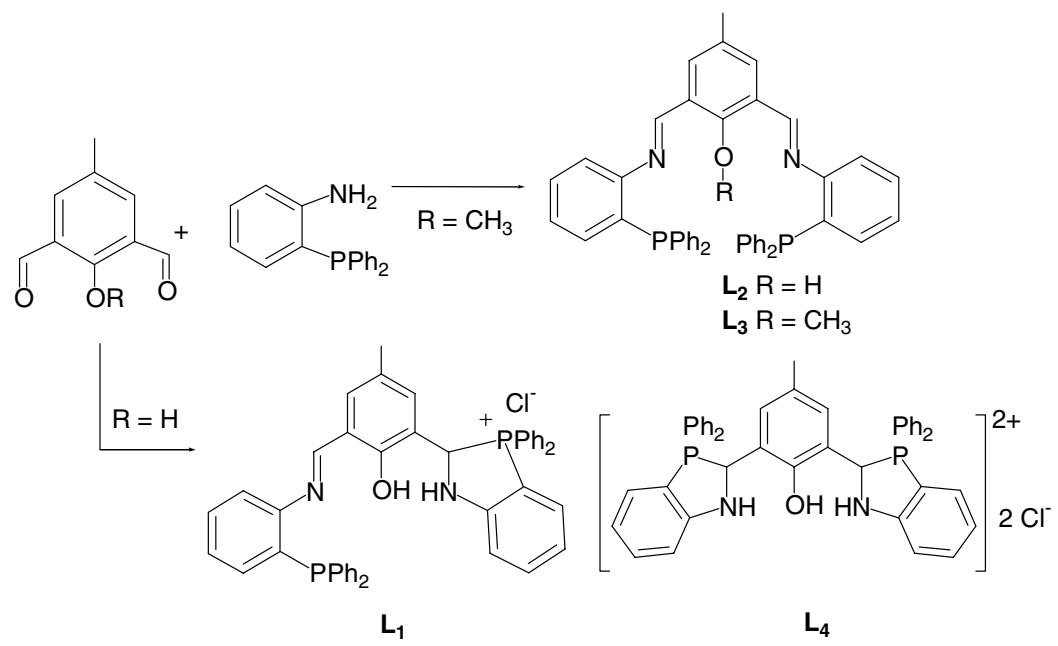

Scheme 1. Ligand synthesis.

trace amount of conc. $\mathrm{HCl}$ in toluene under nitrogen atmosphere afforded the one side cyclized benzoazaphospholium schiff base ligand $\mathbf{L}_{\mathbf{1}}$ instead of the anticipated ligand $\mathbf{L}_{2}$ (Scheme 1). The ${ }^{31} \mathrm{P}$ NMR spectrum showed two absorptions at -14.8 and $36.8 \mathrm{ppm}$, which were corresponding to the tert-phosphine and the cyclized benzoazaphospholium group [11], respectively. The infrared spectrum showed a strong absorption at $1624 \mathrm{~cm}^{-1}$ manifesting the formation of imine functionality, which was also evidenced by the ${ }^{1} \mathrm{H}$ NMR signal at $8.32 \mathrm{ppm}$ for the imino proton. Interestingly, the bis-benzoazaphospholium compound $\mathbf{L}_{\mathbf{4}}$ was obtained when the reaction was carried out in a polar solvent such as dichloromethane (see below).

Under similar conditions, reaction of 2,6-diformyl-4methylanisole with $\mathbf{P} \sim \mathbf{N}$ in a molar ratio of 1:2 afforded the bis-imine ligand $\mathbf{L}_{\mathbf{3}}$ in good yield (70\%). Crystallization from dichloromethane and hexane gave lemon yellow crystals. IR spectrum shows a strong characteristic absorption for imine group at $1617 \mathrm{~cm}^{-1}$. The ${ }^{31} \mathrm{P}$ NMR spectrum exhibits one signal at $-16.1 \mathrm{ppm}$ corresponding to the presence of a tert-diphenylphosphino group. All spectral data including ${ }^{1} \mathrm{H},{ }^{13} \mathrm{C}$ NMR as well as FAB mass spectrum and elemental analysis of $\mathbf{L}_{\mathbf{3}}$ are consistent with the structure proposed. From the above observation, it is assumed that the phenolic proton readily facilitates the cyclization of benzoazaphospholium ring. It has been known that condensation of $\mathbf{P} \sim \mathbf{N}$ with a carbonyl compound in the presence of acid could provide the cyclized benzoazaphospholium products [11].

\subsection{Nickel(II) complexes}

Reaction of $\mathbf{L}_{\mathbf{3}}$ with $\mathrm{Ni}$ (DME) $\mathrm{Cl}_{2}$ (1:2) in dichloromethane resulted in the cyclization of ligand to form the azaphospholium 1 in $28 \%$ isolated yield. (Eq. (1)) Recrystallization from dichloromethane and hexane gave light blue crystals. The ${ }^{31} \mathrm{P}$ NMR spectrum of the compound shows only one singlet absorption at 41.2 ppm, which is typical for the phosphonium group. The $\mathrm{X}$-ray structural characterization of the complex shows the formation of bis-benzoazaphospholium ring of the ligand with the $\left[\mathrm{NiCl}_{4}\right]^{-2}$ as counter anion (Fig. 1). It appeared that the phosphorus and nitrogen donors do not bound to the metal ion. Distances of C(9)-N(2) [1.464(6) $\AA]$ and $\mathrm{C}(28)-\mathrm{N}(1)[1.476(6) \AA]$ are typical for a $\mathrm{C}-\mathrm{N}$ single bond, indicating that the molecule does not include any imine functionality. Examination of the carbon to phosphorus distances and the associated bond angle clearly shows that the phosphorus atom is seated in a tetrahedral geometry, a typical phosphonium salt. It appears that the nickel ions act as Lewis acid to catalyze the cyclization of the phospholium ions and undergo the disproportionation to yield $\left[\mathrm{NiCl}_{4}\right]^{2-}$, which 

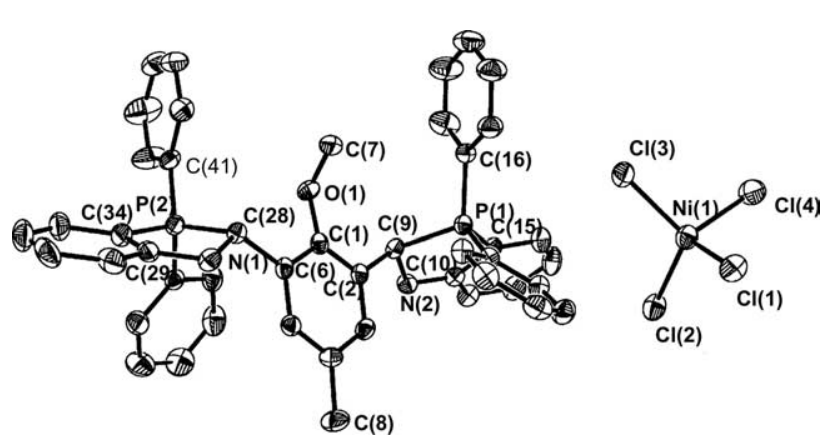

Fig. 1. ORTEP plot of complex 1. Average Ni-Cl $2.257 \AA$, C(2)-C(9)

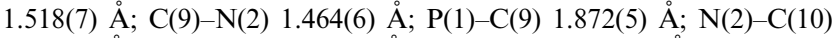

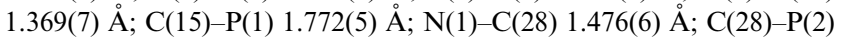
1.857(5) $\AA$; $\mathrm{P}(2)-\mathrm{C}(34) 1.759(6) \AA ; \mathrm{N}(1)-\mathrm{C}(29) 1.391(7) \AA$.

provides the appropriate anions to form the single crystal of $\mathbf{1}$. In fact, some of the starting nickel(II) complex was recovered.

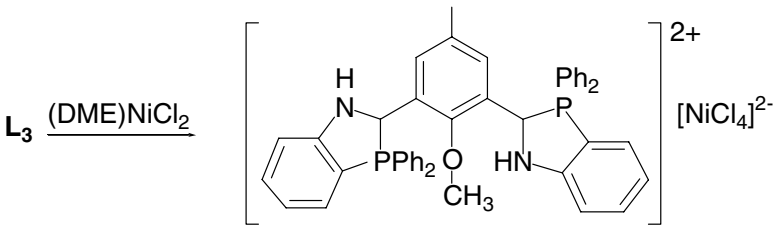

1

On the other hand, template condensation method, a common approach to construct the oxo-bridge bimetallic species, was employed to synthesize the phenoxo bridged dinuclear nickel complex. Thus, a mixture of 2,6-diformyl-4-methylphenol, $\mathbf{P} \sim \mathbf{N},(\mathrm{DME}) \mathrm{NiCl}_{2}$ and triethylamine (molar ratio $=1: 2: 2: 1$ ) in dry methanol under nitrogen at $55{ }^{\circ} \mathrm{C}$ resulted in the formation of the corresponding Schiff base-phosphine mono nickel complex 2 instead of the anticipated dinuclear nickel complex (Eq. (2)). Recrystallization of the crude product from dichloromethane and hexane gave complex $\mathbf{2}$ in the crystalline form. The chemical shift at $39.7 \mathrm{ppm}$ of complex 2 in ${ }^{31}$ P NMR was determined due to the phosphonium group. The formation of benzo-azaphospholium ring might be due to the Lewis acid nature of nickel ion. No ${ }^{31} \mathrm{P}$ NMR signal was observed for the phosphorus coordinated to the nickel center, which might be due to the paramagnetic nature of nickel ion. This is in agreement with the literature known mononuclear nickel complexes of PNO donor ligands [6a]. The NH proton was observed as a doublet at $8.76 \mathrm{ppm}\left(J_{\mathrm{P}-\mathrm{H}}=2.4\right.$ $\mathrm{Hz}$ ) and was confirmed by the $\mathrm{D}_{2} \mathrm{O}$ exchange. The imino proton appeared to be a singlet at $8.41 \mathrm{ppm}$. The two aromatic protons of the phenol are observed as doublets at $8.22(0.8 \mathrm{~Hz})$ and $8.19(0.8 \mathrm{~Hz}) \mathrm{ppm}$. The proton on the carbon of aza-phosphonium ring was observed as a doublet at $6.32 \mathrm{ppm}(1.2 \mathrm{~Hz})$ due to the phosphorus coupling. FAB mass spectrum shows the isotope pattern at $m / z 775$ for the cation part of the complex 2 .<smiles>Cc1cc(C=O)c(O)c(C=O)c1</smiles><smiles>Cc1cc(C2Nc3ccccc3C2[I-])c2on3c4ccccc4n3c3ccccc3[pH]c2c1</smiles>

ORTEP plot of $\mathbf{2}$ with partial atom labeling is presented in Fig. 2. Selected bond distances and bond angles are summarized in Table 1. The charge of nickel ion was neutralized with ligand phenoxide group and chloride anion, whereas the positive charge was located at phosphorus center of the phosphazolium group. The nickel(II) center was seated in a slightly distorted square planar geometry by the coordination of ligand PNO donors and a chloride. The chloride group bound trans to the imine nitrogen. Angles of O-Ni-P $\left[175.19(9)^{\circ}\right]$ and $\mathrm{N}-\mathrm{Ni}-\mathrm{Cl}\left[174.96(9)^{\circ}\right]$ are less than $180^{\circ}$ presumably due to steric arrangement of the $\mathrm{P} \sim \mathrm{N} \sim \mathrm{O}$ donors. Bond distance of the newly formed $\mathrm{C}(9)-\mathrm{P}(2)[1.853(4) \AA]$ is

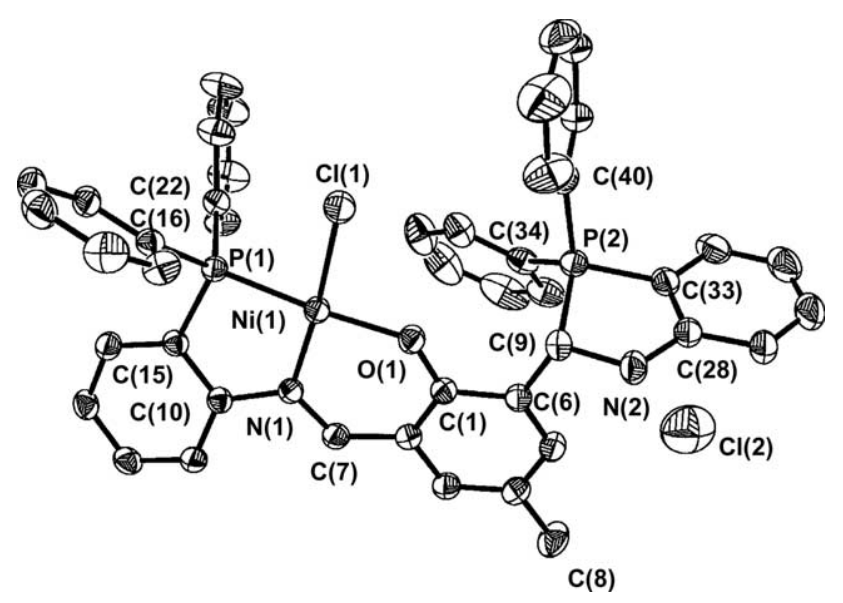

Fig. 2. Molecular structure of complex 2.

Table 1

Selected bond lengths $(\AA)$ and bond angles $\left({ }^{\circ}\right)$ of 2

\begin{tabular}{ll}
\hline $\mathrm{Ni}(1)-\mathrm{O}(1)$ & $1.866(3)$ \\
$\mathrm{Ni}(1)-\mathrm{P}(1)$ & $2.1262(10)$ \\
$\mathrm{C}(7)-\mathrm{N}(1)$ & $1.316(5)$ \\
$\mathrm{P}(2)-\mathrm{C}(9)$ & $1.853(4)$ \\
$\mathrm{Ni}(1)-\mathrm{N}(1)$ & $1.885(3)$ \\
$\mathrm{Ni}(1)-\mathrm{Cl}(1)$ & $2.1861(11)$ \\
$\mathrm{C}(9)-\mathrm{N}(2)$ & $1.460(5)$ \\
$\mathrm{O}(1)-\mathrm{Ni}(1)-\mathrm{N}(1)$ & $95.83(12)$ \\
$\mathrm{N}(1)-\mathrm{Ni}(1)-\mathrm{P}(1)$ & $87.63(9)$ \\
$\mathrm{N}(1)-\mathrm{Ni}(1)-\mathrm{Cl}(1)$ & $174.96(9)$ \\
$\mathrm{O}(1)-\mathrm{Ni}(1)-\mathrm{P}(1)$ & $175.19(9)$ \\
$\mathrm{O}(1)-\mathrm{Ni}(1)-\mathrm{Cl}(1)$ & $89.20(9)$ \\
$\mathrm{P}(1)-\mathrm{Ni}(1)-\mathrm{Cl}(1)$ & $87.33(4)$ \\
\hline
\end{tabular}


longer than all other $\mathrm{P}-\mathrm{C}$ bonds in the complex. The distance of $\mathrm{C}(9)-\mathrm{N}(2)[1.46(5) \AA]$ determines the single bond nature of that bonding, compared to the imine $\mathrm{C}(7)-\mathrm{N}(1)$ distance [1.316(5) $\mathrm{A}]$. It is interesting to note that even though the $\mathrm{N}-\mathrm{H} \cdots \mathrm{O}$ interactions are very strong, the steric bulky benzo-azaphospholium group is arranged towards the nickel complex instead of $\mathrm{NH}$ group.

\subsection{Palladium(II) complexes}

In contrast to the nickel complex, the di-palladium complex $\mathbf{3}$ can be easily obtained by the substitution of COD from (COD)PdMeCl with $\mathbf{L}_{3}$ in a dichloromethane solution. Recrystallization of $\mathbf{3}$ from dichloromethane/hexane gave the resulting complex as an air-stable, light yellowish crystalline complex. The ${ }^{31} \mathrm{P}$ NMR spectrum showed a singlet absorption at 34.31 ppm corresponding to the coordination of phosphine toward palladium center. The ${ }^{1} \mathrm{H}$ NMR spectrum exhibited a doublet at $0.76(1.6 \mathrm{~Hz}) \mathrm{ppm}$ corresponding to the $\mathrm{CH}_{3}$ group bonded to the palladium metal ion in trans arrangement to the imine donor. The ${ }^{13} \mathrm{C}$ NMR absorption at $-1.47 \mathrm{ppm}$ is in agreement with $\mathrm{Pd}-\mathrm{CH}_{3}$ moiety, consistent to the literature known complexes [4]. Owing to the influence of chloride groups on the palladium, the aryl protons of the phenol group shift to downfield from 7.72 to 8.86 ppm.

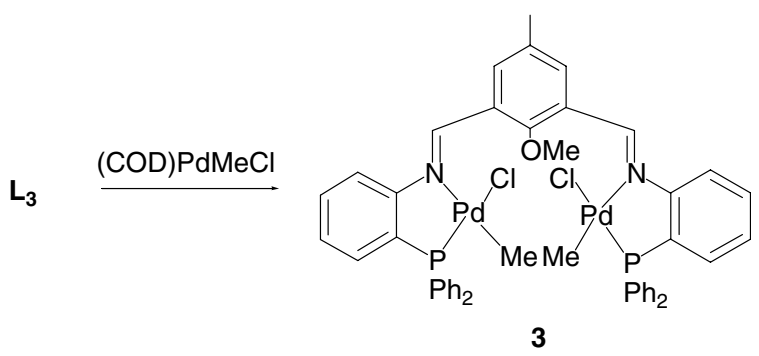

Interestingly, condensation of 2,6-diformyl-4-methylphenol with 2-(diphenylphosphino)-aniline in the presence of $\mathrm{Pd}(\mathrm{COD}) \mathrm{MeCl}$ in dry methanol under basic conditions at $55{ }^{\circ} \mathrm{C}$ provided the one side Schiff base complex 4 in low yields. The FT-IR spectral absorptions at 1660 and $1616 \mathrm{~cm}^{-1}$ show clearly the presence of both the aldehyde and imine functional groups, respectively, in the complex along with the support of ${ }^{1} \mathrm{H}$ NMR signals at 10.75 and $8.85 \mathrm{ppm}$. The ${ }^{1} \mathrm{H}$ NMR spectrum showed the $\mathrm{Pd}-\mathrm{CH}_{3}$ absorption at $0.7 \mathrm{ppm}$ corresponding to the trans arrangement of the methyl group to the imine functionality. The ${ }^{31} \mathrm{P}$ NMR show the coordinated phosphorus signal at $43.71 \mathrm{ppm}$. Overall, the spectral data of $\mathbf{4}$ are quite similar to that of 5 [4], which allow us to assign the structure of $\mathbf{4}$ properly. Further reaction of $\mathbf{4}$ with $\mathbf{P} \sim \mathbf{N}$ provided the complicated product distribution, from which we have not isolated any pure form.
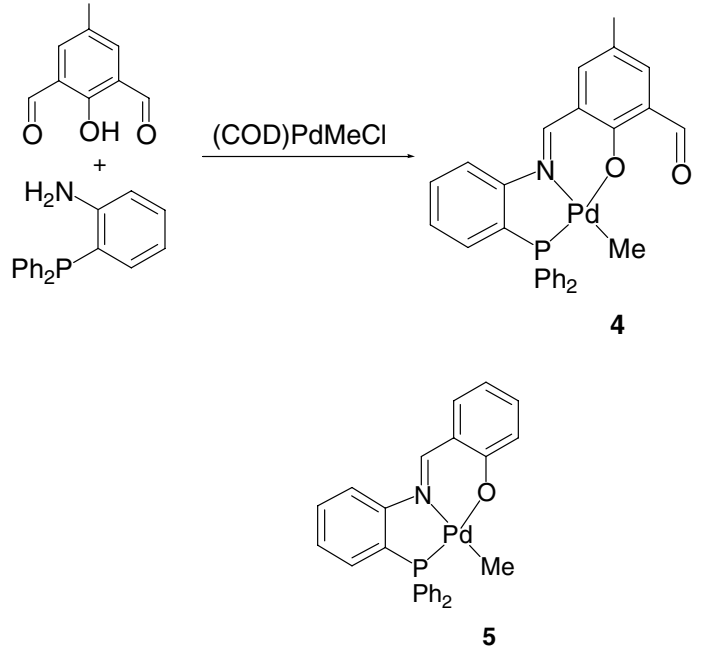

\section{Conclusion}

Through this study, it was found that the imino-phosphine readily underwent cyclization to form the benzoazaphospholium moiety via the nucleophilic attack of phosphine toward imine functionality under acidic conditions. Although donor atoms of ligand $\mathbf{L}_{\mathbf{3}}$ are ready for coordination of two metal ions to form the dinuclear species, the cyclization still takes place prior to the complexation with the use of nickel ions, indicating the Lewis acidic character of nickel ions. In contrast to nickel complexes, the coordination of (COD) $\mathrm{PdMeCl}$ toward $\mathbf{L}_{\mathbf{3}}$ allows to yield the desired bi-metallic species. The construction of multi-metal complexes with PNO-donors is currently under investigation.

\section{Experimental}

\subsection{General}

All reactions, manipulations and purification steps were performed under a dry nitrogen atmosphere. Tetrahydrofuran was distilled under nitrogen from sodium benzophenone ketyl. Dichloromethane and acetonitrile were dried with $\mathrm{CaH}_{2}$ and distilled under nitrogen. Other chemicals and solvents were of analytical grade and were used as received unless otherwise stated. 2,6-Diformyl-4methylphenol [12] and 2-(diphenylphosphino)aniline [13] were synthesized from the reported procedures.

Nuclear magnetic resonance spectra were recorded in $\mathrm{CDCl}_{3}$ on either a Bruker AM-300 or AVANCE-400 spectrometer. Chemical shifts are given in parts per million relative to $\mathrm{Me}_{4} \mathrm{Si}$ for ${ }^{1} \mathrm{H}$ and relative to $85 \% \mathrm{H}_{3} \mathrm{PO}_{4}$ for ${ }^{31} \mathrm{P}$ NMR. Mass spectra were obtained from a Joel JMSD-300 instrument. FT-IR spectra were recorded on Nicolet Magna-IR 550 spectrometer (series II) as $\mathrm{KBr}$ pellets. Elemental analyses were carried out using 
Perkin-Elmer 240C instrument. FAB mass spectra were recorded using Jeol JMSD-300 spectrometer.

\subsection{Synthesis and characterization}

\subsubsection{Preparation of $\boldsymbol{L}_{1}$ and $\boldsymbol{L}_{\boldsymbol{4}}$}

A dry toluene $(10 \mathrm{ml})$ solution of 2,6-diformyl-4methylphenol $(0.164 \mathrm{~g}, 1 \mathrm{mmol})$ was added to 2-(diphenylphosphino)aniline $(0.553 \mathrm{~g}, 2 \mathrm{mmol})$, and $1 \mathrm{drop}$ of conc. $\mathrm{HCl}$ under dry nitrogen atmosphere and stirred at room temperature for about $3 \mathrm{~h}$. The reaction is monitored by ${ }^{31} \mathrm{P}$ NMR spectra. The resulting orange solution was concentrated and washed with hexane several times. Yield: $0.38 \mathrm{~g}, 53 \%$. FT-IR $\left(\mathrm{KBr}, \mathrm{cm}^{-1}\right):\left(v_{\mathrm{C}=\mathrm{N}}\right)$ 1624; ${ }^{1} \mathrm{H}$ NMR $\left(\mathrm{CDCl}_{3}\right) \delta: 2.04$ (s, 3H, $\left.\mathrm{Ar}-\mathrm{CH}_{3}\right), 6.77-$ $7.67(\mathrm{~m}, \mathrm{Ar}), 8.32(\mathrm{~s}, 1 \mathrm{H}, \mathrm{C}=\mathrm{N}) ;{ }^{31} \mathrm{P}$ NMR $\delta:-14.8$, 36.8 ppm. Anal. Calc. for $\mathrm{C}_{45} \mathrm{H}_{37} \mathrm{ClN}_{2} \mathrm{OP}_{2}$ : C, 75.15; H, 5.19; N, 3.90. Found: C, 74.89; H, 5.01; N, 3.66\%.

$\mathbf{L}_{\mathbf{4}}$ was obtained via the similar procedure by running the reaction in dichloromethane: (31\%): ${ }^{1} \mathrm{H}$ NMR $\left(\mathrm{CDCl}_{3} / \mathrm{CD}_{3} \mathrm{OD}\right) \delta: 1.40$ (s, $\left.3 \mathrm{H}, \mathrm{Ar}-\mathrm{CH}_{3}\right), 6.43(\mathrm{~s}, 2 \mathrm{H}$, $\mathrm{CH}), 6.67(\mathrm{~m}, 1 \mathrm{H}, \mathrm{CH}), 6.75(\mathrm{~m}, 2 \mathrm{H}, \mathrm{Ar}), 6.93(\mathrm{~m}$, 2H, Ar), 7.19 (s, 4H, Ar), 7.30 (m, 8H, Ar), 7.50 (m, $8 \mathrm{H}, \mathrm{Ar}), 7.72(\mathrm{~m}, 2 \mathrm{H}, \mathrm{Ar}), 7.89$ (m, 4H, Ar); ${ }^{31} \mathrm{P}$ NMR $\delta$ : 38.9; Anal. Calc. for $\mathrm{C}_{45} \mathrm{H}_{38} \mathrm{Cl}_{2} \mathrm{~N}_{2} \mathrm{OP}_{2}$ : C, 71.53; $\mathrm{H}$, 5.07; N, 3.71. Found: C, 71.22; H, 4.67; N, 3.52\%.

\subsubsection{Synthesis of 2,6-bis[(o-diphenylphosphino)- benzeneimino ]-4-methylanisole $\left(\boldsymbol{L}_{3}\right)$}

A dry toluene $(10 \mathrm{ml})$ solution of 2,6-diformyl-4methylanisole $(0.656 \mathrm{~g}, 4 \mathrm{mmol})$ was added to 2-(diphenylphosphino)aniline ( $2.21 \mathrm{~g}, 8 \mathrm{mmol})$, and 1 drop of conc. $\mathrm{HCl}$ under dry nitrogen atmosphere and stirred at room temperature for about $6 \mathrm{~h}$. The resulting lemon yellow solution was diluted with dichloromethane and treated with aq. $\mathrm{NaHCO}_{3}$ solution. The organic layer was dried over $\mathrm{MgSO}_{4}$ and concentrated. Recrystallization from $\mathrm{CH}_{2} \mathrm{Cl}_{2}$ and hexane afford to the desired compound as lemon yellow crystals. Yield: $2.00 \mathrm{~g}$, $70 \%$. FT-IR $\left(\mathrm{KBr}, \mathrm{cm}^{-1}\right):\left(v_{\mathrm{HC}=\mathrm{N}}\right) 1617 ;{ }^{1} \mathrm{H}$ NMR $\left(\mathrm{CDCl}_{3}\right) \delta: 2.28\left(\mathrm{~s}, 3 \mathrm{H}, \mathrm{Ar}-\mathrm{CH}_{3}\right), 3.35\left(\mathrm{~s}, 3 \mathrm{H}, \mathrm{OCH}_{3}\right)$, $6.86(\mathrm{q}, J=7.6 \mathrm{~Hz}, 2 \mathrm{H}, \operatorname{Ar}-H), 7.02(\mathrm{q}, J=7.6 \mathrm{~Hz}$, $2 \mathrm{H}, \mathrm{Ar}), 7.14(\mathrm{t}, J=7.6 \mathrm{~Hz}, 2 \mathrm{H}, \mathrm{Ar}-\mathrm{H}), 7.28-7.40(\mathrm{~m}$, $22 \mathrm{H}, \mathrm{Ar}), 7.72(\mathrm{~s}, 2 \mathrm{H}, \mathrm{Ar}), 8.43(\mathrm{~s}, 2 \mathrm{H}, \mathrm{C}=\mathrm{N}) ;{ }^{13} \mathrm{C}$ NMR $\left(\mathrm{CDCl}_{3}, 25{ }^{\circ} \mathrm{C}\right) \delta: 20.6\left(\mathrm{Ar}-\mathrm{CH}_{3}\right), 64.8\left(\mathrm{OCH}_{3}\right)$, $117.1,125.9,128.2,128.3,128.5,128.7,129.7,131.6$, $132.5,132.5,132.6,134.0,134.2,136.7,136.8,154.3$, $154.5(\mathrm{C}-\mathrm{O}), 154.8(\mathrm{C}-\mathrm{N}), 159.1(\mathrm{C}=\mathrm{N}) ;{ }^{31} \mathrm{P}$ NMR $\delta$ : -16.11 ppm; FAB mass: $m / z, 697.3[\mathrm{M}]^{+}$. Anal. Calc. for $\mathrm{C}_{46} \mathrm{H}_{38} \mathrm{~N}_{2} \mathrm{OP}_{2}$ : C, 79.30; H, 5.50; N, 4.02. Found: C, 79.25; H, 5.77; N, 3.93\%.

\subsubsection{Complex 1}

(DME) $\mathrm{NiCl}_{2}(0.220 \mathrm{~g}, 1 \mathrm{mmol})$ was added to a solution of $\mathbf{L}_{\mathbf{3}}(0.348 \mathrm{~g}, 0.5 \mathrm{mmol})$ in dry dichloromethane $(10 \mathrm{ml})$ under nitrogen and the mixture was stirred at room temperature for $1.5 \mathrm{~h}$. The resulting light orange solution was concentrated under vaccum and the solid obtained was washed with hexane. Recrystallization from dichloromethane and hexane obtained light blue crystals and orange crystals. Spectral characterization of the orange crystals shows $\mathrm{Ni}(\mathrm{DME}) \mathrm{Cl}_{2}$ compound, while the blue crystals showed the formation of the complex 1. Yield: $0.160 \mathrm{~g}, 28 \% .{ }^{1} \mathrm{H}$ NMR $\left(\mathrm{CDCl}_{3} / \mathrm{CD}_{3} \mathrm{OD}\right)$ $\delta: 1.42\left(\mathrm{~s}, 3 \mathrm{H}, \mathrm{Ar}-\mathrm{CH}_{3}\right), 3.11\left(\mathrm{~s}, 3 \mathrm{H}, \mathrm{OCH}_{3}\right), 6.32(\mathrm{~s}, 1 \mathrm{H}$, $\mathrm{CH}), 6.50(\mathrm{~m}, 1 \mathrm{H}, \mathrm{CH}), 6.69(\mathrm{~m}, 1 \mathrm{H}, \mathrm{Ar}), 6.87(\mathrm{~s}, 1 \mathrm{H}$, Ar), $7.06(\mathrm{~s}, 4 \mathrm{H}, \mathrm{Ar}), 7.20(\mathrm{~m}, 8 \mathrm{H}, \mathrm{Ar}), 7.51(\mathrm{~m}, 8 \mathrm{H}$, Ar), 7.69 (m, 2H, Ar), $7.82(\mathrm{~m}, 4 \mathrm{H}) ;{ }^{31} \mathrm{P}$ NMR $\delta: 41.2$; Anal. Calc. for $\mathrm{C}_{46} \mathrm{H}_{40} \mathrm{Cl}_{4} \mathrm{~N}_{2} \mathrm{OP}_{2} \mathrm{Ni}$ : C, 61.44; $\mathrm{H}, 4.48$; $\mathrm{N}, 3.12$. Found: C, 61.84; H, 4.57; N, 3.00\%.

\subsubsection{Complex 2}

2,6-Diformyl-4-methylphenol (0.082 g, $0.5 \mathrm{mmol})$ in $20 \mathrm{ml}$ dry methanol was added to anhydrous (DME)$\mathrm{NiCl}_{2}(0.220 \mathrm{~g}, 1 \mathrm{mmol})$ and 2-(diphenylphosphino)aniline $(0.277 \mathrm{~g}, 1 \mathrm{mmol}), \mathrm{Et}_{3} \mathrm{~N}(0.050 \mathrm{mg}, 0.5 \mathrm{mmol})$ and the reaction mixture was heated to $55{ }^{\circ} \mathrm{C}$ for $2 \mathrm{~h}$. The resulting solution was concentrated and the solid was washed with ether, dried under vacuum. Recrystallization from dichloromethane and hexane gave the crystals suitable for X-ray analysis. Yield: $0.300 \mathrm{~g}, 52 \%$. FT-IR $\left(\mathrm{KBr}, \mathrm{cm}^{-1}\right):\left(v_{\mathrm{C}=\mathrm{N}}\right) 1623 ;{ }^{1} \mathrm{H}$ NMR $\left(\mathrm{CDCl}_{3}\right) \delta: 2.04$ $\left(\mathrm{s}, 3 \mathrm{H}, \mathrm{Ar}-\mathrm{CH}_{3}\right), 6.29(\mathrm{~d}, J=1.2 \mathrm{~Hz}, 1 \mathrm{H}, \mathrm{CH}), 6.91(\mathrm{t}$, $J=4 \mathrm{~Hz}, 2 \mathrm{H}, \mathrm{Ar}), 7.07$ (t, $J=4 \mathrm{~Hz}, 2 \mathrm{H}, \mathrm{Ar}), 7.22$ (m, $J=8 \mathrm{~Hz}, 2 \mathrm{H}, \mathrm{Ar}), 7.36(\mathrm{~m}, 8 \mathrm{H}, \mathrm{Ar}), 7.53(\mathrm{q}, J=8 \mathrm{~Hz}$, $8 \mathrm{H}, \operatorname{Ar}), 7.65$ (q, $J=8 \mathrm{~Hz}, 2 \mathrm{H}, \operatorname{Ar}), 7.84(\mathrm{~d}, J=8 \mathrm{~Hz}$, $4 \mathrm{H}, A r), 8.17$ (q, $J=8 \mathrm{~Hz}, 2 \mathrm{H}, \operatorname{Ar}), 8.41(\mathrm{~s}, 1 \mathrm{H}$, $\mathrm{HC}=\mathrm{N}), 8.70\left(\mathrm{~d}, J_{\mathrm{NH}-\mathrm{P}}=2.4 \mathrm{~Hz}, \mathrm{NH}\right) ;{ }^{31} \mathrm{P}$ NMR $\left(\mathrm{CDCl}_{3}\right) \delta$ : 39.41; FAB mass: $m / z 775\left[\mathrm{Ni}\left(\mathrm{L}^{4}\right) \mathrm{Cl}\right]^{+}$. Anal. Calc. for $\mathrm{C}_{45} \mathrm{H}_{35} \mathrm{~N}_{2} \mathrm{O}_{2} \mathrm{P}_{2} \mathrm{NiCl}_{2}$ : C, 66.68; $\mathrm{H}, 4.48 ; \mathrm{N}$, 3.46. Found: C, 66.44; H, 4.68; N, 2.99\%.

\subsubsection{Complex 3}

$\mathrm{Pd}(\mathrm{COD}) \mathrm{MeCl}(0.265 \mathrm{~g}, 1 \mathrm{mmol})$ was added to a solution of $\mathbf{L}_{\mathbf{3}}(0.348 \mathrm{~g}, 0.5 \mathrm{mmol})$ in dry dichloromethane (10 $\mathrm{ml})$ under nitrogen and the mixture was stirred at room temperature for $1 \mathrm{~h}$. The resuting light yellow solid was filtered and washed repeatedly with hexane and ether and dried under vaccum. Recrystallization from $\mathrm{CH}_{2} \mathrm{Cl}_{2} /$ hexane gave 3 as crystalline solids. Yield: 0.545 g, 89\%. FT-IR $\left(\mathrm{KBr}, \mathrm{cm}^{-1}\right):\left(v_{\mathrm{C}=\mathrm{N}}\right) 1624 ;{ }^{1} \mathrm{H}$ NMR $\left(\mathrm{CDCl}_{3} / \mathrm{CD}_{3} \mathrm{OD}\right) \delta: 0.76\left(\mathrm{~d}, 6 \mathrm{H}, J=1.6 \mathrm{~Hz}, \mathrm{Pd}-\mathrm{CH}_{3}\right)$, $2.49\left(\mathrm{~s}, 3 \mathrm{H}, \mathrm{Ar}-\mathrm{CH}_{3}\right), 3.74\left(\mathrm{~s}, 3 \mathrm{H}, \mathrm{OCH}_{3}\right), 7.11(\mathrm{t}, J=2$ $\mathrm{Hz}, 2 \mathrm{H}, \mathrm{Ar}-\mathrm{H}), 7.31$ (t, $J=2 \mathrm{~Hz}, 2 \mathrm{H}, \mathrm{Ar}-\mathrm{H}), 7.33-7.52$ (m, 22H, Ar), 7.57 (t, $J=2 \mathrm{~Hz}, 2 \mathrm{H}, \mathrm{Ar}-\mathrm{H}), 8.87$ (s, 2H, $\mathrm{Ar}-\mathrm{H}), 8.92(\mathrm{~s}, 2 \mathrm{H}, \mathrm{C}=\mathrm{N}) ;{ }^{13} \mathrm{C}$ NMR $\delta:-1.47(\mathrm{Pd}-$ $\left.\mathrm{CH}_{3}\right), 20.9\left(\mathrm{Ar}-\mathrm{CH}_{3}\right), 65.3\left(\mathrm{OCH}_{3}\right), 118.9,119.0,127.0$, $128.2,128.7,129.0,129.4,129.5,131.2,131.7,131.9$, $132.9,132.9,133.0,133.6,133.8,133.9,136.3,156.3$, 164.7(C $=\mathrm{N}) ;{ }^{31} \mathrm{P}$ NMR $\delta: 34.3$. FAB mass: $m / z 1018$ $[\mathrm{M}]^{+}$. Anal. Calc. for $\mathrm{C}_{48} \mathrm{H}_{44} \mathrm{Cl}_{2} \mathrm{~N}_{2} \mathrm{OP}_{2} \mathrm{Pd}_{2}$ : C, 57.05; H, 4.39; N, 2.77. Found: C, 56.89; H, 4.41; N, 2.94\%. 


\subsubsection{Complex 4}

A mixture of 2,6-diformyl-4-methylphenol $(0.082 \mathrm{~g}$, $0.5 \mathrm{mmol})$, (COD)PdMeCl (0.265 g, $1 \mathrm{mmol})$, and 2(diphenylphosphino)aniline $(0.277 \mathrm{~g}, 1 \mathrm{mmol})$ in $20 \mathrm{ml}$ dry methanol and $\mathrm{Et}_{3} \mathrm{~N}(0.5 \mathrm{mmol})$ was heated to $55^{\circ} \mathrm{C}$ with stirring for $2 \mathrm{~h}$. The resulting solution was concentrated and the solid was washed with ether, dried under vacuum. Recrystallization from dichloromethane and hexane gave $\mathbf{4}$ as light yellow crystalline solids. Yield: $0.080 \mathrm{~g}, 13 \%$. FT-IR $\left(\mathrm{KBr}, \mathrm{cm}^{-1}\right):\left(v_{\mathrm{C}=\mathrm{O}}\right) 1660,\left(v_{\mathrm{C}=\mathrm{N}}\right)$ 1623. ${ }^{1} \mathrm{H}$ NMR $\left(\mathrm{CDCl}_{3}\right) \delta: 0.70\left(\mathrm{~s}, 3 \mathrm{H}, \mathrm{Pd}-\mathrm{CH}_{3}\right) 2.24$ (s, 3H, Ar- $\left.\mathrm{CH}_{3}\right), 7.26(\mathrm{~m}, 1 \mathrm{H}, \mathrm{Ar}), 7.32(\mathrm{~s}, 1 \mathrm{H}, \mathrm{Ar})$, 7.33-7.55 (m, 8H, Ar), 7.61-7.66 (m, 4H, Ar), 7.73$7.76(\mathrm{~m}, 1 \mathrm{H}, \mathrm{Ar}), 7.80(\mathrm{~s}, 1 \mathrm{H}, \mathrm{Ar}), 8.85(\mathrm{~s}, 1 \mathrm{H}, \mathrm{HC}=\mathrm{N})$, $10.75(\mathrm{~s}, 1 \mathrm{H}, \mathrm{HC}=\mathrm{O}) .{ }^{13} \mathrm{C} \mathrm{NMR}\left(\mathrm{CDCl}_{3}\right) \delta:-0.80(\mathrm{~d}$, $\left.\mathrm{J}=1.2 \mathrm{~Hz}, \mathrm{Pd}-\mathrm{CH}_{3}\right), 19.95(\mathrm{Ar}-\mathrm{CH} 3), 115.81,122.67$, $123.46,127.69,127.79,128.74,128.85,129.05,129.84$, $130.39,130.93,131.09,131.12,132.67,133.22,133.64$, $133.86,136.58,144.04,153.81,154.00,157.57,169.61$ $(\mathrm{C}=\mathrm{N}), 192.03(\mathrm{C}=\mathrm{O}) ;{ }^{31} \mathrm{P}$ NMR $\delta$ : 43.71; FAB mass: $\mathrm{m} / z$ 543.0 [M] ${ }^{+}$. Anal. Calc. for $\mathrm{C}_{28} \mathrm{H}_{24} \mathrm{NO}_{2}$ PPd: C, $61.83 ; \mathrm{H}, 4.45 ; \mathrm{N}, 2.58$. Found: C, 61.91; H, 4.62; N, $2.60 \%$.

\subsection{X-ray crystallographic analysis}

Crystals suitable for X-ray determination were obtained for $\mathbf{1}$ and $\mathbf{2} \cdot \mathrm{CH}_{3} \mathrm{OH} \cdot 2 \mathrm{H}_{2} \mathrm{O}$ by the slow diffusion of the hexane into the dichloromethane/methanol solution of the complexes at room temperature. The cell parameters were determined at $298 \mathrm{~K}$ using a Nonius

Table 2

Crystallographic data of complexes $\mathbf{1}$ and $\mathbf{2}$

\begin{tabular}{lll}
\hline Complex & $\mathbf{1}$ & $\mathbf{2}$ \\
\hline Formula & $\mathrm{C}_{46} \mathrm{H}_{40} \mathrm{Cl}_{4} \mathrm{~N}_{2} \mathrm{OP}_{2} \mathrm{Ni}$ & $\mathrm{C}_{46} \mathrm{H}_{36} \mathrm{Cl}_{2} \mathrm{~N}_{2} \mathrm{O}_{5} \mathrm{P}_{2} \mathrm{Ni}$ \\
Formula weight & 899.27 & 888.33 \\
Crystal system & monoclinic & monoclinic \\
Space group & $P 2_{1}$ & $P 2_{1} / n$ \\
$a(\AA)$ & $11.8110(2)$ & $14.2020(10)$ \\
$b(\AA)$ & $15.8030(2)$ & $19.2730(10)$ \\
$c(\AA)$ & $12.0330(2)$ & $15.9530(10)$ \\
$\alpha\left({ }^{\circ}\right)$ & 90 & 90 \\
$\beta\left({ }^{\circ}\right)$ & $106.1280(10)$ & $102.7460(10)$ \\
$\gamma\left({ }^{\circ}\right)$ & 90 & 90 \\
$V\left(\AA^{3}\right)$ & $2157.56(6)$ & $4258.97(5)$ \\
$Z$ & 2 & 4 \\
$D_{\text {calc }}\left(\mathrm{Mg} / \mathrm{m}^{3}\right)$ & 1.384 & 1.385 \\
$F(000)$ & 928 & 1832 \\
Crystal size (mm) & $0.20 \times 0.15 \times 0.10$ & $0.30 \times 0.25 \times 0.20$ \\
$\theta$ Range $\left({ }^{\circ}\right)$ & $2.14-25.07$ & $1.68-25.00$ \\
Number of reflections & 12849 & 83163 \\
$\quad$ collected & & \\
Number of independent & 7115 & 7479 \\
$\quad$ reflections & & \\
Refined method & full-matrix least- & full-matrix least- \\
& squares on $F^{2}$ & squares on $F^{2}$ \\
$R[I>2 \sigma(I)]$ & 0.0506 & 0.0643 \\
Goodness-of-fit on $F^{2}$ & 1.120 & 1.076 \\
\hline
\end{tabular}

kappa CCD diffractometer with graphite-monochromated Mo K $\alpha$ radiation $(\lambda=0.071073 \AA)$. All the structures were solved by direct methods (SHELXTL) and all of the non-hydrogen atoms refined anisotropically. Structural refinements were done by full-matrix least-squares methods on $F^{2}$. Absorption corrections were done using multi-scan methods. Crystal data for complexes are listed in Table 2.

Crystallographic data (excluding structure factors) for the structure reported in this work have been deposited with the Cambridge Crystallographic Data Center: CCDC-250230 for 1 and CCDC-250231 for 2. Copies of this information can be obtained free of charge and by application to CCDC, 12 Union Road, Cambridge CB2 1EZ, UK (fax: +44 1223336 033; e-mail: deposit@ ccdc.cam.ac.uk or www: http://www.ccdc.cam.ac.uk).

\section{Acknowledgments}

We thank the National Science Council, Taiwan, ROC for the financial support.

\section{References}

[1] A.L. Gavrilova, B. Bosnich, Chem. Rev. 104 (2004) 349, and references cited therein.

[2] (a) For recent reviews, see P. Braunstein, F. Naud, Angew. Chem., Int. Ed. 40 (2001) 680;

(b) M. Gómez, G. Muller, M. Rocamora, Coord. Chem. Rev. 193-195 (1999) 769;

(c) C.S. Slone, D.A. Weinberger, C.A. Mirkin, Prog. Inorg. Chem. 48 (1999) 233;

(d) P. Espinet, K. Soulantica, Coord. Chem. Rev. 193-195 (1999) 499

(e) G. Helmchen, A. Pfaltz, Acc. Chem. Res. 33 (2000) 336.

[3] F. Speiser, P. Braunstein, L. Saussine, R. Welter, Organometallics 23 (2004) 2613, and references cited therein.

[4] P.-Y. Shi, Y.-H. Liu, S.-M. Peng, S.-T. Liu, Organometallics 21 (2002) 3203.

[5] J.R. Dilworth, S.D. Howe, A.J. Hutson, J.R. Miller, J. Silver, R.M. Thompson, M. Harman, M.B. Hursthouse, J. Chem. Soc., Dalton Trans. (1994) 3553.

[6] (a) J. Parr, A.M.Z. Slawin, Inorg. Chim. Acta 303 (2000) 116; (b) P. Bhattacharyya, J. Parr, A.M.Z. Slawin, J. Chem. Soc., Dalton Trans. (1998) 3609.

[7] P. Bhattacharyya, M.L. Loza, J. Parr, A.M.Z. Slawin, J. Chem. Soc., Dalton Trans. (1999) 2917.

[8] E.K. Van den Beuken, N. Veldman, W.J.J. Smeets, A.L. Spek, B.L. Feringa, Organometallics 17 (1998) 636.

[9] P.-Y. Shi, Y.-H. Liu, S.-M. Peng, S.-T. Liu, J. Chin. Chem. Soc. 50 (2003) 89.

[10] K. Rajender Reddy, W.-W. Tsai, K. Surekha, G.-H. Lee, S.-M. Peng, J.-T. Chen, S.-T. Liu, Dalton Trans. (2002) 1776.

[11] S. Doherty, J.G. Knight, T.H. Scanlan, M.R.J. Elsegood, W. Clegg, J. Organomet. Chem. 650 (2002) 231.

[12] R.R. Gagne, C.L. Spiro, T.J. Smith, W.R. Hamann, W.R. Thies, A.K. Shiemke, J. Am. Chem. Soc. 103 (1981) 4073.

[13] M.K. Cooper, J.M. Downes, P.A. Duckworth, Inorg. Synth. 25 (1989) 129. 